\title{
Article \\ Social Vulnerability and Touristification of Historic Centers
}

\author{
Carmen Mínguez ${ }^{1}$, María José Piñeira ${ }^{2, *}$ and Alfonso Fernández-Tabales ${ }^{3}$ \\ 1 Department of Geography, Faculty of Geography \& History, Complutense University of Madrid, \\ 28040 Madrid, Spain \\ 2 Department of Geography, Faculty of Geography \& History, University of Santiago de Compostela, \\ 17572 Santiago de Compostela, Spain \\ 3 Department of Physical Geography \& Regional Geographical Analysis, Faculty of Geography \& History, \\ 41004 Seville, Spain \\ * Correspondence: mariajose.pineira@usc.es; Tel.: +34-881-812-626
}

Received: 30 July 2019; Accepted: 14 August 2019; Published: 19 August 2019

\begin{abstract}
Historic centers have suffered different processes of neglect, occupation, segregation, gentrification, and touristification as a result of changes in demand and policies. Currently, they are going through a homogenization process motivated by tourist pressure, which is causing the expulsion of the local population; this is a common topic of interest for media and political agendas, which requires scientific analysis. This research aims at identifying the winning and the losing tourist groups in the historic center of Seville. It is structured in two parts: a conceptual one based on the bibliographic review with which one wants to know how the current society responds to tourist pressure through defining and characterizing the processes of substitution of uses and inhabitants, and another empirical one in which the analysis of statistical indicators (demographic, economic, and residential) treated with Geographic Information System (GIS) allows us to measure the degree of existing vulnerability and analyze social and spatial effects caused by the tourism in Seville.
\end{abstract}

Keywords: vulnerability; right to the city; tourism rents; Seville

\section{Introduction}

The traditional city is subject to continuous transformation processes. Its consideration as an item of consumption has resulted in a number of urban transformations meant to attract more consumers/visitors. Administrations have accordingly adjusted to the rationales of the (property and tourism) market, which eventually becomes the driving force for processes of urban regeneration and renewal, while the guidelines for urban planning and residents' social wellbeing and needs remain on the back burner.

The city has shifted to being managed as an enterprise, running the risk that, in some sectors such as historic centers, their multiple functions, complexity, and vital nature are lost until reaching a point in which the neighborhood is not inhabited but rather consumed. As a result, the traditional city becomes a decorative wrap for a standardized social life with an increasingly homogeneous landscape and a supposed urban lifestyle characterized by widespread repetition of standard scenes and products [1]. The urban image has been trivialized, which hides the reality experienced by neighborhood residents, sometimes close to areas heavily frequented by tourists in which the absence of urban improvements, joblessness, social unrest, or evictions have plunged the inhabitants into a situation of vulnerability-a vulnerability that local administrations have kept in the background for decades.

In Spain, it was not until the year 2011 and the 15th of May movement that attention began to be paid to them. At the time, citizens upset about their economic situation, austerity policies, and 
corruption cases began to claim the right to create the city, to decide, and to participate [2]. They wanted a new, more transparent and effective urban governance model that would guarantee basic rights (housing, education, and health) that were being undermined by the austerity plans. The attainment of municipal power by new left-wing forces emerging from the citizens' movement in 2015 brought a bit of hope to the social sectors that bore the brunt of the crisis. Cities such as Barcelona, Madrid, Cádiz, A Coruña, or Santiago de Compostela became laboratories where the new format for managing the city and ensuring citizen participation in its projects were tested. However, numerous problems arose- excessive red-tape, the difficulty of changing inherited work synergies, the lack of qualified personnel, the lack of budget funding, tensions within governing political coalitions, etc.

One legislative term later, unemployment and a shortage of jobs and decent housing continue to be problems for Spanish cities. Consequently, in 2018, 26.6\% of the Spanish population was still in a situation of vulnerability [3]. A vulnerability in which sectors such as historic city centers have increased due to the appearance of new factors such as tourism, which generates segregation processes (resulting from higher housing prices) and discontent among residents, whose lower income segments end up being expelled.

In this article, we first approach the concept of vulnerability before analyzing how it is impacted by tourism activity. We focus on residential vulnerability, paying close attention to the problem of tourist rentals. To that end, we use the historic center of Seville as a case study to see just how far tourism aggravates the existing situation of vulnerability by means of gentrification and residential filtering processes.

\section{Vulnerability: The Concept and Its Determinant Factors}

The United Nations indicates that the concept of social vulnerability refers to a situation where the population is exposed to certain risks and uncertainties but has little ability to protect or defend itself against them and deal with their negative consequences [4].

As in other European countries, in Spain, the crisis resulting from the crash of the real estate bubble in 2008 and its prolonged effects over the next decade caused the middle class to see their living conditions worsen. A high percentage of the population saw their income fall because they were in a situation of unemployment or had lost their homes and saw their basic rights (education, health, and housing) shaken due to austerity policies imposed by the government to control spending and rein in public debt [5].

Many researchers have echoed the problem, attempting to measure its intensity and ascertain which cities and districts require more attention by administrations. Particularly noteworthy internationally are the works by the following: Rainer Wehrhahn [6], on the production of urban spaces in crisis contexts or the negotiation of dispossession; Penny Koutrolikou [7], who discusses how crises and the urban intersect and affect citizenship rights and practices in different cities in Southern Europe; Emma Heffernan, John McHale, and Niamh Moore-Cherry [8], who explain how the impact of austerity unfolded and how it has been experienced by different groups within society in Ireland; Michael Janoshka [9], with his studies on the housing problem in cities such as London or others in Greece, as well as the topic of gentrification and resistance in Latin American cities; and Amendola, Rossi, and Vecci [10], who examine the phenomenon of vulnerability and poverty in Italy. Standing out in Spain is the work by R. Méndez and S. Sánchez [11], who studied the deep and long-lasting decline in which Spanish cities are currently immersed; they end up calling them "shrinking cities". For their part, M. J. Piñeira together with J. M. Trillo, R. Lois, and J. M. González [12,13] analyzed the social segregation processes manifested in those cities and the need to conceive measures that promote a better standard of living and more sustainable urbanism and that encourage more participative democracy. Also interesting is the research conducted by Alaminos, Penalva, and Domenech [14] on community reactions to the economic and the social crisis, such as charity, anonymous donations, food banks, community kitchens, organized occupation of housing, or interchange networks; the work by Parreño and Dominguez in collaboration with other authors $[15,16]$ on vulnerability with 
respect to affected groups such as immigrants; or that of Carman, Vieira, and Segura [17], who classified different categories of vulnerability, some already known (socio-demographic, socioeconomic, residential, subjective) and others harder to discern, such as hidden (invisible) segregation or indolence (self-segregation). Finally, O. Nel-lo $[18,19]$ explained the social problem existing in Catalan cities and urban districts in crisis with situations of substandard housing, overcrowding, and problems accessing basic services.

Worthy of special attention are platforms such as the Urban Vulnerability Observatory promoted by the Ministry of Development, which provides an Atlas of Urban Vulnerability in Spain for the years 2001 and 2011 [20], and specific in-depth studies on vulnerability in major Spanish cities for the years 1991, 2001, and 2011 [21], whose most prominent tool is a Catalogue of Vulnerable Neighborhoods. These publications provide an overview of the state of urban vulnerability at national and intra-urban scales, which can be complemented by the Atlas of the Crisis [22].

All of them have two approaches in common: (1) they develop an analysis methodology based on the combination of multiple indicators, among which are the unemployment rate, the aging index, the degree of literacy, the unoccupied buildings, and the percentage of families living in buildings in bad conditions; and (2) they consider that vulnerable neighborhoods are places where those difficulties accumulate determined by the higher presence and the combination of socio-demographic, socioeconomic, residential, and subjective factors.

That is why most researchers classify vulnerability in four major blocks [12,18,20,23-25].

- Environmental vulnerability: linked to excessive water and power consumption, ineffective treatment of pollution and solid waste, and activities that endanger harmonic and environmentally sustainable urban development in which the landscape's identity is preserved and consolidated;

- Economic vulnerability: linked to higher rates of joblessness and the decline of the construction sector that sustained the economic model before the crisis. The most affected groups are young people, who are forced to keep studying (without a vocation or to occupy their time) or emigrate abroad in search of better opportunities, and the long-term jobless and foreigners, above all those who had earned a living with precarious contracts and are now unemployed;

- Social vulnerability and inequality in access to goods and services: this means a lower standard of living in certain sectors of society owing to problems accessing the labor market and appropriate housing, education, health, leisure, consumption, social participation, environmental quality, etc;

- Residential vulnerability: given the impossibility of accessing housing in line with personal economic resources, a shortage of housing to meet needs and the lack of stability and/or security resulting from continual use of a dwelling.

One might think that the slight improvement in macroeconomic terms recorded in Spain since 2013 and the recovery in some indicators means a reduction in vulnerability levels. However, the opposite occurred because the economic recovery was not accompanied by an equivalent residential, social, and environmental improvement. First of all, there has been a worrisome upsurge in pollution levels in 26 Spanish cities, among them Bilbao, Zaragoza, Valencia, San Sebastián, Alicante, and Seville [26]. It is consequently a problem that no longer affects only the largest cities. According to the 8th Report on Poverty in Spain [3], 8\% of the population suffers from cold at home (in 2009, it was $7.2 \%$ ), a quarter of those over 25 years old do not have their own income or earn less than 535 Euros a month, and $10 \%$ of workers continue to lose $25 \%$ of their income each year due to precarious job conditions. Additionally, regarding the housing problem, it continues to be the second aspect that most concerns the population in cities such as Barcelona, Madrid, and Palma, where rents have shot up. On the other hand, according to judiciary statistics, evictions continue, with a total of 368,591 recorded since 2013 , of which $58.9 \%$ were for non-payment of rent and $41.1 \%$ for non-payment of the mortgage.

We can consequently state that vulnerability is still present in many districts of our cities, including the historic centers, and that the social cohesion policies promoted by municipal governments have generally had less impact than expected. 
In this context, some cities have seen tourism as the solution to their problems, because it generates more employment and revitalizes urban sectors such as the historic centers. However, some authors have warned about the social profitability of its benefits, its impacts on the environment, precarious jobs, and higher prices (especially rents), the trivialization and the loss of identity of the area, as well as unaccounted public spending or the opportunity cost of tourist specialization that subtracts resources from productive diversification (Figure 1).

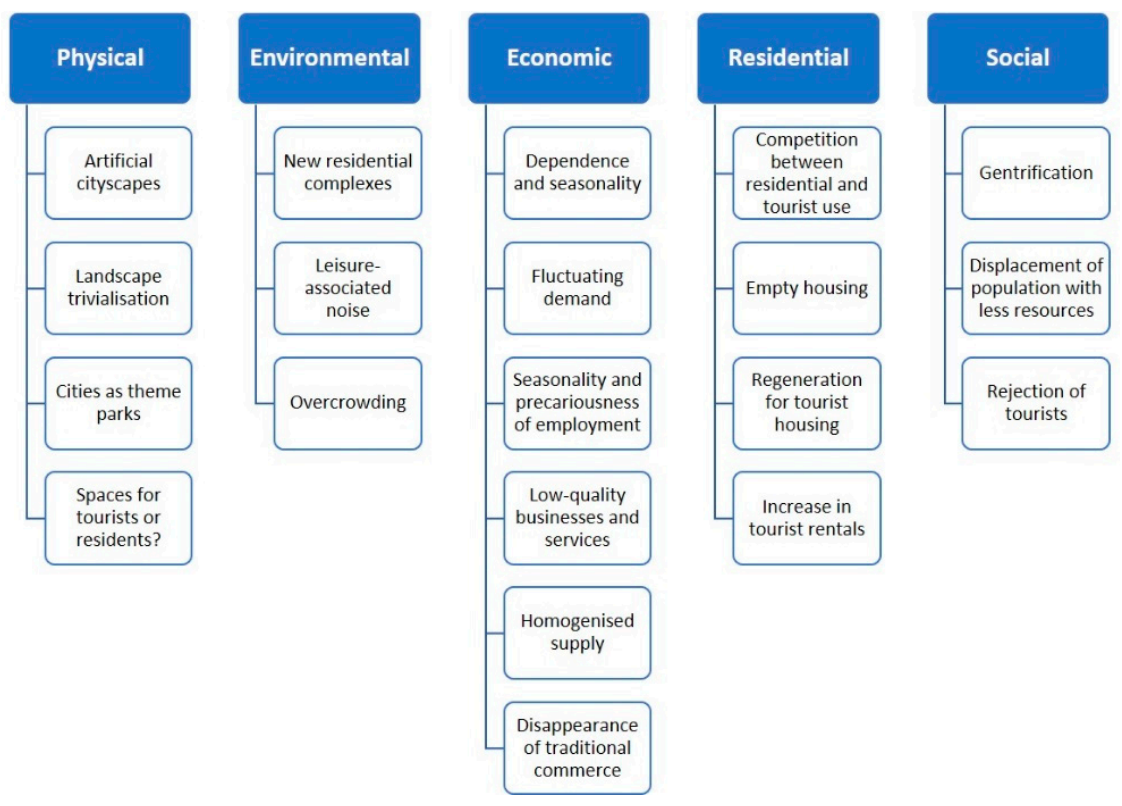

Figure 1. Impacts of tourism activity on historic centers. Source: own production.

The population residing in historic centers has consequently been subject to threats and risks of an activity beyond their control without mechanisms to mitigate them. In a short period of time, they have seen how tourists are shaping their neighborhood and determining the uses and the functions of spaces and infrastructures so that significant budget outlays are destined for them. All this is based on the desires of visitors, which are placed before the needs of the resident population. Tourism activity gradually ends up competing with the day-to-day life of the historic centers with the rights of tourists prevailing over those of residents. The result is the commoditization and the denaturation of local symbols and the appropriation of spaces (public squares, businesses, streets) by tourism activities, short-circuiting the continuity of traditional practices [27] along with some processes of invasion/succession, gentrification, and residential filtering that entail a process of population replacement, the introduction of an outsider group, and the exit of the original inhabitants [28].

In this regard, there is a danger that residents will have a negative perception of tourists, of the neighborhood where they live, and of their own social conditions, which may lead to a feeling of discontent and may or may not correspond to some objective vulnerability indicators. Thus, it is fitting to not only speak of environmental, economic, residential, and social vulnerability but also of psychosocial vulnerability.

In the following section, we specifically approach one of the factors generating more vulnerability for residents in historic centers-tourist rentals. We discuss what the phenomenon consists of, which groups are benefiting from it, and which are suffering its negative effects.

\section{Rental of Tourist Housing and Its Impact on Urban Dynamics}

The huge impact of the so-called sharing economy on the tourism sector is currently a well-recognized reality [29-32]. Beyond the effect on other activities (such as automobile transport or tourist guide services), the phenomenon with the highest economic, social, and spatial impact doubtless 
corresponds to the rapid and massive expansion of housing rentals for use by tourists supplied via online platforms (Airbnb, HomeAway, Housetrip, etc). Indeed, it can be stated that it has become the decisive phenomenon in the functional transformation of central zones of the world's major cities, which have shifted from being residential and commercial to becoming spaces devoted to tourist lodgings with higher intensity depending on the tourist attractions present in each city. The intensity and the speed of those platforms' penetration, especially Airbnb as a hegemonic company in the activity [33], has, from the standpoint of the theory of disruptive innovation [34], led to that company being labeled the best example of such disruptive innovation in contemporary tourism activity [35]. In less than half a decade, it has shifted from being a niche product (for young people or experienced tourists seeking a lodging type more integrated in the local community) to being a conventional product open to mass demand.

This phenomenon has been dealt with extensively in recent scientific literature. A significant part of the production concerns legal [36], economic [37,38], and business-related [39-41] aspects. Contributions that consider this activity to be a new form of tourist experience linked to direct contact with the local population and distanced from the accommodation formalities in the regulated offering are also frequent $[31,42]$.

From a spatial perspective, there is already a substantial group of insights based on analysis of the location of such housing in cities and its relationship with other elements such as tourism resources or the hotel offering. Among those contributions, the following can be cited: Arias and Quaglieri [43], on the location of lodgings offered in Airbnb and their relationship with areas of high hotel presence in Barcelona; Gutiérrez-Puebla et al. [44], with analysis of the spatial correlation between the offering of Airbnb, hotels, and photos uploaded to the Panoramio platform (also in Barcelona); Dudas et al. [45], who studied the concentration of Airbnb offerings compared to the population's age, the available real property, and the closeness of tourism resources in New York City; or Yrigoy [46], who studied the supply's concentration in the historic center of Palma de Mallorca. In more detail, Ioannides et al. [33] conducted an in-depth analysis of the case of the Lombok neighborhood in Utrecht.

One of the most fruitful research lines focuses on studying the phenomenon's social repercussions on urban populations, especially with respect to distortion of the property market boom (especially rental prices) and gentrification and touristification of urban districts [47]. These processes were analyzed in different cities such as New Orleans [48], Los Angeles [49], San Francisco, Valparaíso [50], and the previously mentioned New York, [45]. Other studies hold that these processes are very complex and that tourist housing rentals can only explain part of the price rises [51]. The phenomenon is also analyzed from angles that are more specific to or focused on particular aspects of the respective processes, such as: (1) the so-called commercial gentrification or the disappearance of traditional businesses for residents and their replacement by franchised establishments for tourists [52,53]; (2) the exploitation of the less-qualified population working in the activity [54]; or (3) the role played in these processes by the concentration of the so-called creative classes in certain sectors of the city who act as a vanguard or precedent for touristification [55]. Finally, there is also a focus on diagnosing its negative effects on the hotel industry at destinations where rental housing ends up competing for the same overall demand [56]. The papers that compare and even quantitatively estimate the negative effects (on both income and jobs) for local societies owing to this transfer of demand from the hotel offering to rentals are of particular interest (see the estimate for Spain's Costal del Sol done by Fuentes and Navarrete [57]).

The focus assumed by this article is accordingly based on approaching the phenomenon by considering the assessment of its positive and negative effects and, more specifically, the assessment of groups or activity segments that it either benefits or harms. In this respect, the following can be said to benefit from the phenomenon:

- First, tourist demand itself, which now has the possibility of accessing lodgings cheaper than the traditional supply at such destinations by means of online platforms that are easy to access and use with a very diverse and large offering;

- The local owners of housing that can be included in the rental market who see the value of their property assets boosted and their income rise substantially through the supply of new housing or 
the switch from rentals for long-term residential use to tourist rentals for short stays with high user rotation;

- Agents who act as intermediaries between suppliers and prospective users, as indicated in the above points, referring to the companies behind the online platforms and the local property agents who have gradually oriented their activity to managing a more or less large group of dwellings, acting as intermediaries between the individual owners, the platforms, and the end users;

- Investors in property assets outside the destination, often international investment funds that acquire buildings in areas of tourism interest for the express purpose of renting them out $[49,58]$. The influence of these agents on the activity has grown as the high profitability obtained from the investments has been demonstrated. Indeed, various studies point out that major global property sector agents have shifted their activity from the purchase of property assets for subsequent sale to rental offerings [59]. This is a key factor for understanding the extent of the phenomenon, at least in major European and North American cities. In this respect, the two major multinational investment funds now dominating the Spanish market can be cited as Blackstone Group and Cerberus Capital Management, both based in the USA;

- The construction sector-above all, the part that specializes in renovating homes-as real property in historic town centers is often quite old and hence requires renovation work before being placed on the rental market;

- Establishments that sell food, given the visitors' usual practice of acquiring food to be consumed in the rented housing;

- Tourism-related companies such as restaurants, guide services, or souvenir shops, which see their earnings rise due to the higher tourist influx.

The following stand out among the groups harmed by the phenomenon:

- Residents of neighborhoods that experience the phenomenon, who see their day-to-day environment change to become a tourism space with a high rotation rate of visitors, accompanied by problems stemming from their mass arrival $[60,61]$, such as noise, inappropriate schedules, perception of insecurity due to unknown people transiting buildings, deterioration of their common areas, changes in the type of nearby business establishments, modification of the traditional urban scene, etc;

- Renters, a resident group that can be labeled the one most affected by this process in which the problems of vulnerability that constitute the core theme of this article are concentrated. The conflict situation is generated due to higher rents in the city's tourist zones owing to the higher benefits from offering those buildings for short-stay tourism rentals instead of long-term residential rentals [62]. These higher prices are leading to the expulsion of rental residents in such areas who cannot pay the higher rents that owners apply to their contracts. They are consequently displaced to other, more peripheral areas of the city with lower prices. The arrival of these displaced groups in a first peripheral zone likewise raises the respective rents, displacing in turn some of its population to another more peripheral zone, and so on [63]. Ultimately, a wave of higher rents is generated, even in areas not affected by touristification, with the result that the residential rental market throughout the city is generally more expensive;

- Companies and workers involved in other lodging modalities, especially hotels. In the early stages of the phenomenon, it was believed that tourist rental housing would not directly compete with hotels, as it addressed other demand segments that sought differential features such as direct contact with the local population [42]. However, the currently prevailing analyses indicate that the price factor plays the decisive role when it comes to choosing one or another offering [64], whereby it can be stated that they directly compete against the regulated offering. Part of the hotel sector will thus find it impossible to compete against the comparatively low prices of rental housing, diminishing their ability to attract the demand and their profitability. This aspect is especially significant for local economies and populations, as all studies $[56,57]$ have shown that 
the economic (effects caused in other sectors) and the social (regarding generation and stability of jobs) impacts are higher in hotel-related activity compared to that of tourist rental housing;

- The state as a whole, represented in the intake of resources via taxation for public finance. One of the repeatedly indicated problems of tourist rental housing [65] has been their fiscal opacity due to the specific features of occasional activity in private homes scattered around the city with scant regulation (until recently) and that are very hard to properly inspect. This has led to very little rigor regarding compliance with tax obligations, with the hotel sector frequently issuing accusations of unfair competition. Yet, once the initial stage of its sudden emergence was over, and given the extent of the phenomenon, public administrations around the world have been striving to impose tighter control over that fiscal opacity, improving the respective collection mechanisms. In the Spanish case, Royal Decree 1070/2017 of 29 December requires that intermediate platforms must identify the building, its owner, the number of days the dwelling will be used, the amount received, and the respective means of payment. This took force fully in 2019, whereby it is still too early to assess its effectiveness;

- Traditional businesses, the reverse of what was indicated for the tourism-oriented establishments that have benefited. Traditional businesses are doubly affected by higher rental prices due to the higher demand for space, the payment capacity of large franchise chains that settle in the respective districts, and the gradual replacement of the traditional local population by high-rotation tourist demand, whereby they lose their traditional clientele, making it hard for them to survive $[53,66]$. The end result is the disappearance of a large part of the traditional commercial offerings in those neighborhoods, which in turn affects the vulnerability of their resident population, who lose the commercial fabric that serviced their daily lives beyond the effects derived from trivialization of the urban scene that accompanies these replacement processes;

- Finally, reference must be made to the negative effects on elements that do not belong or cannot be assigned to specific groups, rather affecting the whole community. These are elements such as the cityscape, the tangible historic heritage (when the ability of monuments or spaces to accommodate tourists is exceeded), or the intangible heritage [understood to be citizens' ways of life and manners relating to their city, sometimes resulting from identity-based processes that developed over centuries (traditions, festivals or social habits in public spaces)], which are trivialized or changed as residential districts are transformed into tourism spaces [67].

Based on the above description of those who stand to win or lose due to the phenomenon, this investigation focuses on the resulting conditions for local populations of the tourism destination apart from other considerations such as the general future of the activity, the evolution of national or regional gross domestic product (GDP), or the level of the territory's ability to attract outside investment. From this standpoint, most of the aforementioned studies consider that the common good of the pre-existing local populations is one of the major sacrifices as the phenomenon expands $[53,68,69]$, and that, given the extent of the phenomenon and its effects, it cannot be conceived (or dealt with by public administration) as being a simple economic relationship between private individuals because it notably affects general aspects of the city's life [70]. For that reason, increasingly more regulations are being approved. These aim to regulate (if not restrict) tourist rental housing, and all of them are based on the basic principle of placing the local population's needs-the right to decent housing among them-above the legitimate profit-making goals of the agents involved. Notably, in the Spanish case in this respect are the Special Urban Lodging Plan (PEUAT) approved in 2017 in Barcelona and the Special Plan for Regulating Third-Party Use in the Accommodation Category (PEH) approved in 2019 in Madrid.

Tourism's presence is therefore added to a known list of phenomena, such as access to and quality of housing, mobility [71], and security or services, among others, which have caused displacements in search of spaces that better fit the socio-labor conditions, even attaining what has been called the geography of opportunity [72]. 


\section{Seville: A City Consolidating as a Tourist Destination}

The city of Seville was chosen as the case study for this research due to its significance as a tourist destination (as is described further on) and the intensity and the speed of the recorded changes. Seville is the capital of the Autonomous Community of Andalusia (Figure 2), the most populous city in southern Spain (688,711 inhabitants in 2018, according to the Municipal Register), and Spain's third-ranking city in tourism activity after Madrid and Barcelona.

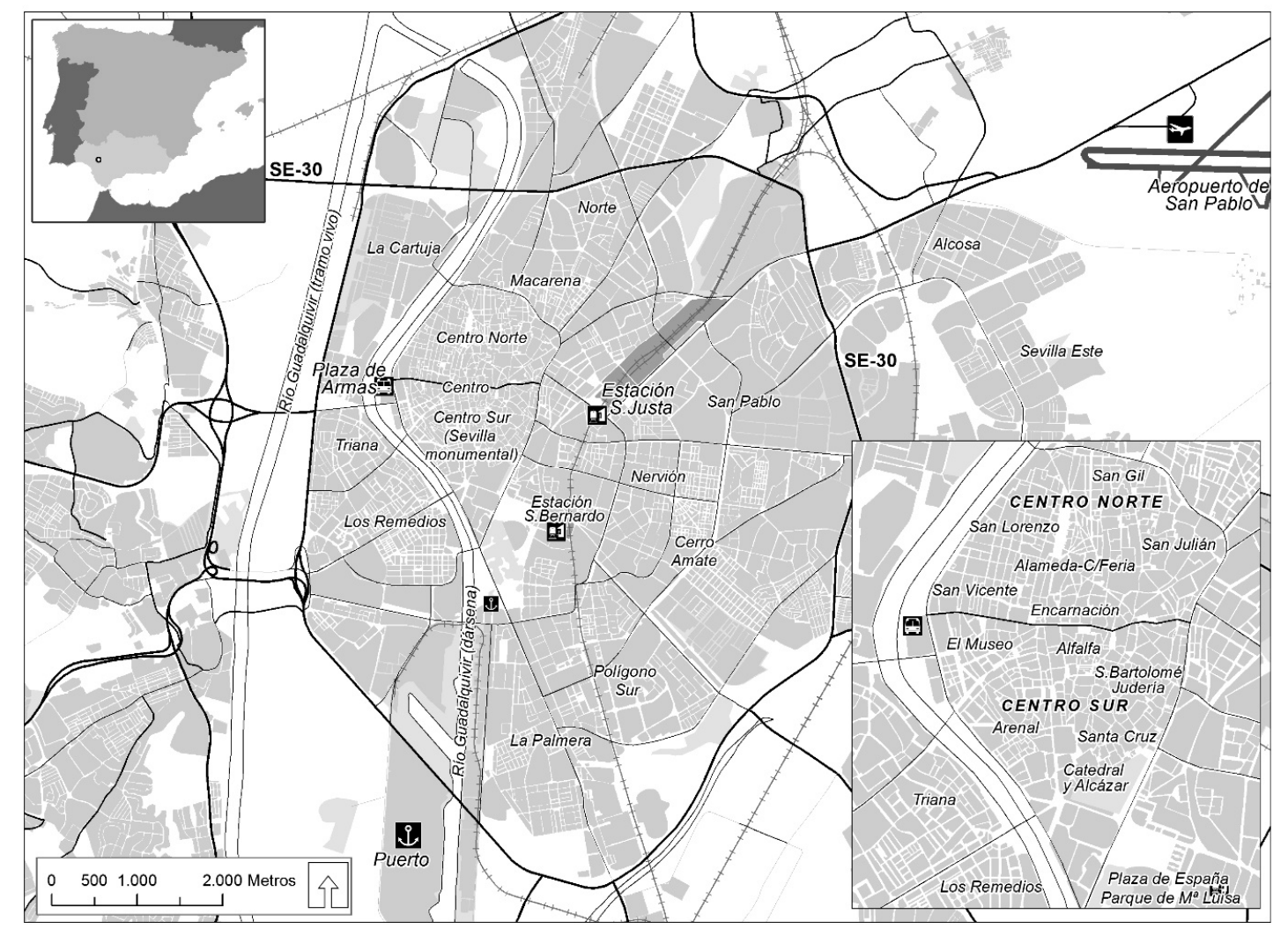

Figure 2. Location of the city of Seville and its historic center. Source: own production.

In recent years, it has experienced rapid growth of tourism activity. Its respective activity levels were already high; since the early 20th century, it has received high tourist influxes due to its heritage resources [73]. However, the increase recorded in the last decade in the context of recovery from the crisis has surpassed all previous periods, as shown in Table 1, which uses overnight stays recorded in hotel establishments as an indicator due to its statistical reliability uses. As can be seen, the annual average increase during the period 2014-2018 reached 9.08\%; for overnight stays generated by foreign visitors, it rose to a very considerable $12.62 \%$ annually.

Table 1. Overnight stays in hotel establishments in Seville (2010, 2014, 2018).

\begin{tabular}{cccccc}
\hline & $\mathbf{2 0 1 0}$ & $\mathbf{2 0 1 4}$ & $\begin{array}{c}\text { \% Avg. Annual } \\
\text { Increase 2010-2014 }\end{array}$ & $\mathbf{2 0 1 8}$ & $\begin{array}{c}\text { \% Avg. Annual } \\
\text { Increase 2014-2018 }\end{array}$ \\
\hline Spanish & $1,566,614$ & $1,755,507$ & 3.01 & $2,066,734$ & 4.43 \\
Foreigners & $1,766,253$ & $2,297,922$ & 7.53 & $3,458,315$ & 12.62 \\
Total & $3,332,867$ & $4,053,429$ & 5.40 & $5,525,049$ & 9.08 \\
\hline
\end{tabular}

Source: National Statistics Institute.

This rapid increase can be noted in many other indicators, such as airport passenger arrivals, number of hotel accommodations, restaurant establishments, or visits to major landmarks. All figures 
converge on an undeniable reality-the city is undergoing a period marked by the most growth of tourism activity in its entire history, surpassing even what was experienced during the most important event to occur in the city, the 1992 Universal Exposition.

The growth of tourism activity is not only reflected by the statistical data; an enlargement of the city's tourism space has also occurred, understood to be the area that experiences a notable presence of tourist companies and visitors [74]. The most significant expansion direction has been within the historic city center, from the traditionally visited southern half toward the northern half, comprising working-class neighborhoods distant from tourist flows until the beginning of the 21st century.

These recent phenomena are presented as the culmination of a much longer process that affects the city's traditional popular districts. These neighborhoods (Triana, the Alameda de Hércules and the northern part of the historic center taken together, and San Bernardo) have been experiencing a process of regeneration and urban and social transformation largely sponsored by the public administration (e.g., the San Luis-Alameda Urban Plan from 1994) since the 1990s [75]. The results have been a process of replacement of the original resident population, i.e., the working (and in some cases, the marginal) classes, by upper-middle-class residents. At the same time, and especially in the northern part of the historic center, the so-called "creative classes" have been settling [76]. Altogether, this has culminated in a far-reaching social transformation of those sectors, which some authors have called a clear example of gentrification [77].

After this stage, which can be framed between the last decade of the 20th century and the first decade of the 21st century, recent impacts of the aforementioned touristification have occurred in these spaces. The impacts are manifested by the proliferation of tourist rental housing, the replacement of traditional businesses by others oriented towards tourist demand, and the rapid increase in residential rents. The sum of these factors has resulted in a second process of population expulsion, now involving the middle and the creative classes (generally young people who live in rental housing) being displaced to more peripheral and cheaper areas of the city. The central parts are therefore left to residents with higher economic capabilities and to high-rotation tourist accommodations [78].

In Seville, this situation has led to the emergence of heated debate in news media and academic circles. The interest focuses on the effects these dynamics are generating, the resulting city model, and the right to the city [27], understood as being the need to build a city in accordance with the needs of its residents and not its visitors. Furthermore, incipient movements and social platforms resisting the touristification of Seville have begun to appear [79], such as the assembly group Cactus (https://cactusevilla.wordpress.com/) or the \#SetNet network, in which a group of European cities (including Barcelona, Palma de Mallorca, Málaga, Seville, Girona, the Canary Islands, San Sebastián, and Pamplona) promote activities against the mass influx of tourists. One of them is the founding manifesto against such touristification. It highlights tourism-derived problems such as increased precariousness and reduction of the right to housing due to the difficulty of access caused by uncontrolled rent increases, the transformation of local commerce, or the generation of waste.

\section{Objectives and Methods}

This was an eminently quantitative investigation that aims to accomplish the following objectives:

- To delve into the concept of vulnerability associated with the proliferation of tourist rental housing (TRH) as a new interpretation for assessing the effects of tourism's growth in historic town centers, the aim being to thereby progress from a theoretical concept to a practical instrument to assist management;

- To design an urban vulnerability indicator associated with TRH based on a combination of demographic, social, economic, and housing variables;

- To test, in reality, the indicator's possibilities by applying it to the historic center of the city of Seville. 
To that end, an important review of the current literature on urban vulnerability, urban tourism and, more specifically, tourist rental housing was first carried out. The result was a theoretical approach to the problem, the factors that determine it, and the corresponding winning and losing groups.

An indicator of social vulnerability associated with TRH was then designed by combining socioeconomic and housing variables (Table 2). These choices were justified based on bibliographical readings, the consultation of platforms specializing in vulnerability such as the Observatory of Urban Vulnerability in Spain, and contributions from experts. The experts met in Santiago de Compostela in October 2018 to participate in the roundtable on Citizen Participation and Resilience during the seminar on New Regional and Urban Governance Models in the 21st Century. Among them were representatives from the Regional Federation of Madrid Neighbour Associations, the Anti-Eviction Platform of Pontevedra, the European Anti-Poverty Network, and the non-profit organization (NGO) Manos Unidas-Santiago.

Table 2. Variables and sources.

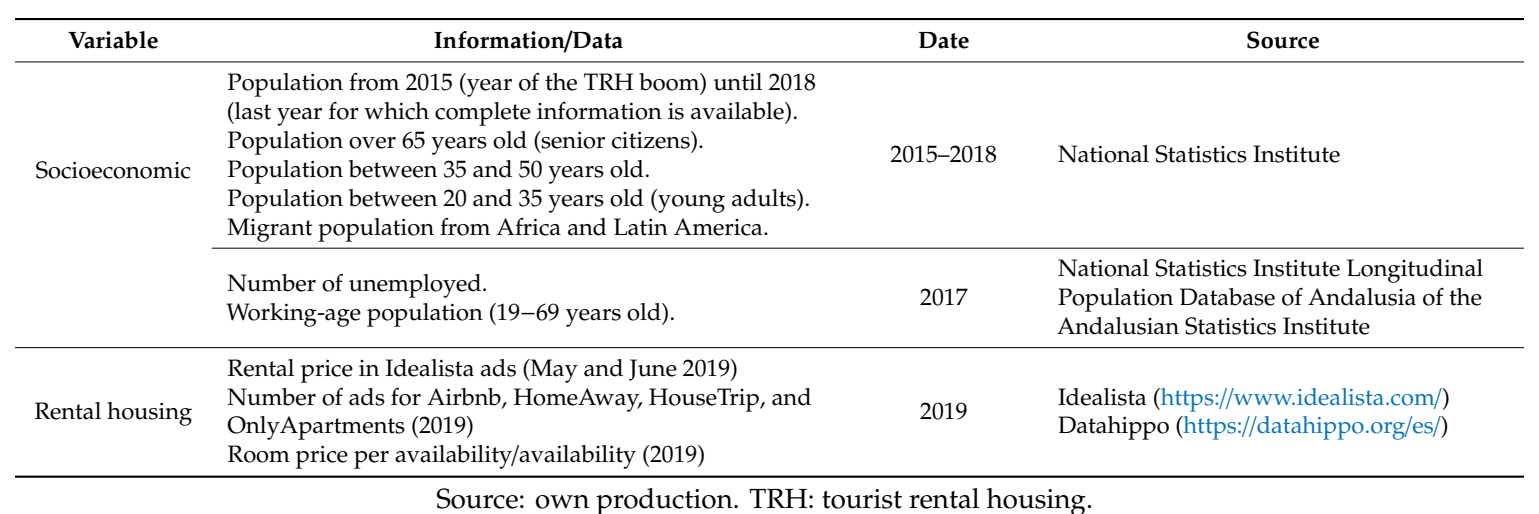

Source: own production. TRH: tourist rental housing.

The variables in the socioeconomic block refer to groups more vulnerable due to TRH. Documents from the 8th Foessa Report [80], the Red Cross Social Vulnerability Report, or the Atlas of Urban Vulnerability [81] agree that the young population, adults between 35 and 50 years old, senior citizens, and the unemployed are the new profiles of populations vulnerable to the advance of tourist rentals.

The problems young people face when seeking their first jobs and the precarious nature of the respective contracts limit their ability to pay high rents or buy a home. Eurostat figures indicate that, in $2017,28.7 \%$ of young people in Spain were unemployed and that $57.9 \%$ of those who worked had temporary contracts. These circumstances hamper the earning capacity of young people and limit their emancipation process. The result is that $91.3 \%$ of young people between 20 and 24 years old and $61.7 \%$ of those between 25 and 29 years old continue to live with their parents. These percentages are quite far from those recorded in Europe, which are $74.1 \%$ and $39 \%$, respectively.

In the case of senior citizens over 65 years old, the vulnerability is relative and is associated with a two aspects, economic and social. It is considered relative because senior citizens usually own their own home and benefit from a retirement pension, though it is certain that, in many cases, it is not enough to meet monthly costs or pay the rent if it is very high. On the other hand, the vulnerability is associated with the importance of social relationships, health and mobility, social participation, and safe and pleasant neighborhoods for the wellbeing of the elderly. Those aspects may be endangered by processes such as gentrification and touristification by reducing their secure ability to move about the neighborhood due to the mass influx of tourists, impinging on public spaces where neighbors socializes, and generating more sound pollution.

For its part, the group between 35 and 50 years old corresponds to young people who were 25 years old a decade ago when the crisis broke out. This is the group that has most suffered its impact, both when seeking jobs and when attempting to buy or rent a place to live. It has also been one of the most affected by mortgage executions or evictions; according to the study on Housing Emergency in 
Catalonia. Impact of the Mortgage Crisis on the Right to Health and Children's Rights [82], the average age of affected people was around 43-44 years old.

All the consulted experts and reports on vulnerability agree when they state that unemployment places people in a situation of vulnerability grounded on financial insecurity when it comes to meeting their own needs. Those paying mortgages have been affected by mortgage executions and evictions and have had to switch to renting a home. However, the higher rental prices in historic city centers have caused populations to be displaced to peripheral districts. The situation suffered by the group of immigrants from Africa and Latin America is similar. The authorization to work and its processing can substantially limit their ability to find work or hold a job. Without a job, it is very hard for them to be able to buy a home, thus they must rent one.

In the housing block, two variables were chosen-density of tourist housing compared to total housing and profitability of tourist rentals compared to traditional rentals. In this case, the premise from the start was the one defended by the Anti-Eviction Platform (PAH-Plataforma anti-desahucios) in the discussion panel on Housing is a Right, Not a Luxury, Not an Asset. It is consequently understood that the higher the density of tourist housing is, the smaller the proportion of housing for residential rentals will be. This circumstance in turn leads to historic centers being occupied by tourists and losing residents, limiting the possibilities for neighborhood renewal, care, and social life. For that reason, we considered the population trend during the period from 2015 to 2018 as a variable from the socioeconomic block. The boom in platforms such as Airbnb extended the belief that profitability of tourism rentals is much higher than residential rentals, mainly in housing situated close to tourist zones. Thus, in some blocks of neighborhoods such as Sol in Madrid, Eixample in Barcelona, Santa Cruz in Seville, and Ciutat Vella in Valencia, housing offered by Airbnb already accounts for $20 \%$ of dwellings.

Once the variables were selected, the data acquisition entailed the consultation of many sources. All were analyzed at the census tract scale because it is the unit of statistical information with the most detail. It also enables the establishment of homogeneous spatial zones from the land-use standpoint.

All the information was analyzed using ArcGis 10.3 and grouped per the different join options (attributes and spatial location). For that reason, it was previously processed. In the case of information from the National Statistics Institute (INE), information on new tracts had to be updated, as their boundaries can change over time. For its part, the information from the Longitudinal Population Database of Andalusia referring to a statistical grid measuring $25 \mathrm{~m}$ on each side was transferred to the census tracts proportional to the area occupied in each of them. Finally, data from the two sources associated with housing were also adjusted for respective comparison. In both cases, the price per room per month was calculated in both modalities. For that reason, in the case of TRH, the average availability of lodging for each tract was calculated. Advertisements in the Idealista portal were obtained by its Application Programming Interface (API), which enabled the downloading of 566 geo-localized rental offerings. For its part, Datahippo enabled the downloading via its webpage of 7433 geo-localized ads, which were reviewed to avoid reiterations or repetitions.

First, the variables were calculated using the available statistical information: (1) population evolution between 2015 and 2018 (\%); (2) ageing rate-population over 65 years old compared to total population (\%); (3) mature adult rate-population between 35 and 50 years old compared to total population (\%); (4) young adult rate-population between 20 and 35 years old compared to total population (\%); (5) immigrant rate-migrant population from Africa and Latin America compared to total population (\%); (6) unemployment rate-number of jobless compared to the working-age population (\%); (7) density of tourist dwellings with respect to total housing (\%); and (8) profitability of tourist rentals versus traditional rentals.

Each variable was then separately mapped and, depending on the values, it was determined which tracts were most vulnerable for that value. Thus, in all of them, the mean total of values for the historic center of Seville was used as a differentiating threshold.

Each variable was assigned a weight according to its impact on vulnerability generated by TRH (Table 3). For that reason, ordinary least squares (OLS) analysis was conducted for each of the variables 
to ascertain its relationship with the tourist rental housing (Table 4). The results obtained indicated that the variables with more incidences with respect to residential vulnerability corresponded to the density of tourist housing and the profitability of tourists versus residential rentals; they were thus assigned the maximum weight of 4 . These variables were followed in importance by the unemployed group and the group of foreigners from African and Latin America, both of which are highly rental dependent and very sensitive to rent increases. Both were weighted with a value of 3 . The other variables of the socioeconomic block were weighted less. The group of young people and young adults was given a value of 2 because, compared to the previous groups, this group is less vulnerable because it includes a family support network. Finally, the lowest weighting value, 1, was assigned to the group of senior citizens over 65 years old and the evolution of the population, two variables that have less direct impact on residential vulnerability according to OLS.

Table 3. The results of the variables and their weighting.

\begin{tabular}{lcccc}
\hline & Minimum & Maximum & Mean & Weighing \\
\hline Population evolution 2015-2018 & -11.21 & 4.06 & 2.82 & 1 \\
Population over 65 years old & 12.30 & 33.28 & 20.64 & 1 \\
Population between 20 and 35 years old & 12.57 & 18.56 & 15.62 & 2 \\
Population between 35 and 50 years old & 18.69 & 33.11 & 25.50 & 2 \\
Foreign population & 0.3 & 3.68 & 1.27 & 3 \\
Unemployed population & 7.5 & 49 & 15 & 3 \\
Density of tourist dwellings with respect to total housing & 0.01 & 1.76 & 0.24 & 4 \\
Profitability of tourist rental/traditional rental & 44.71 & 210.62 & 72.84 & 4 \\
\hline
\end{tabular}

Source: own production.

Table 4. Ordinary least squares (OLS) analysis.

\begin{tabular}{lc}
\hline & $\mathbf{R}^{2}$ \\
\hline Population evolution 2015-2018 & 0.27 \\
Population over 65 years old & 0.04 \\
Population between 20 and 35 years old & 0.01 \\
\hline \multicolumn{2}{c}{ Source: own production. }
\end{tabular}

Once all of the maps were homogenized and weighted, they were rasterized so their values could be summed up with Raster Calculator. The end result was a map with values between 1 and 16 resulting from the combination of all the variables. For the final mapping, they were vectored, and the resulting numeric figures (between 1 and 16) were grouped, establishing three levels that differentiated low, medium, and high vulnerability.

\section{Results}

The results after applying the eight selected variables to the census tracts are shown in Table 5 and Figure 3 Figure 4 Figure 5 Figure 6 (maps 6.1 to 6.8). In them, the heterogeneous nature of situations present in this historic city center can be appreciated. However, broadly speaking, it can be seen that historical patterns have maintained; some zones to the south and the west show higher socioeconomic levels compared to the more impoverished zones to the north and the east, with exceptions that are indicated further on. 
Table 5. Result of applying the eight selected variables by census tract.

\begin{tabular}{|c|c|c|c|c|c|c|c|c|}
\hline Census Tracts & 1 & 2 & 3 & 4 & 5 & 6 & 7 & 8 \\
\hline 001 & 1.19 & 14.98 & 16.01 & 24.80 & 0.96 & 9.38 & 0.16 & 33.37 \\
\hline 002 & -3.48 & 18.80 & 18.47 & 24.04 & 0.98 & 13.87 & 0.22 & 77.43 \\
\hline 003 & -1.96 & 17.38 & 16.52 & 27.78 & 0.85 & 10.78 & 0.09 & 79.91 \\
\hline 004 & 0.86 & 26.41 & 12.89 & 24.28 & 1.49 & 12.53 & 0.12 & 40.55 \\
\hline 005 & 0.47 & 19.34 & 16.86 & 25.94 & 1.77 & 10.16 & 0.22 & 50.39 \\
\hline 006 & -0.72 & 20.81 & 18.56 & 26.22 & 2.25 & 9.88 & 0.13 & 77.12 \\
\hline 007 & -5.72 & 25.66 & 15.20 & 21.18 & 0.75 & 11.67 & 0.30 & 15.73 \\
\hline 008 & -0.29 & 27.08 & 14.99 & 23.03 & 0.58 & 13.82 & 0.07 & 48.95 \\
\hline 009 & 0.47 & 17.58 & 12.57 & 31.78 & 1.16 & 7.08 & 0.19 & 56.32 \\
\hline 010 & -0.59 & 21.20 & 14.92 & 25.85 & 1.11 & 12.98 & 0.12 & 42.98 \\
\hline 011 & -3.90 & 20.46 & 14.77 & 25.39 & 0.77 & 14.69 & 0.13 & 42.62 \\
\hline 012 & -2.41 & 20.83 & 15.05 & 25.31 & 1.16 & 8.55 & 0.16 & 36.30 \\
\hline 013 & -2.06 & 20.52 & 14.21 & 25.53 & 0.40 & 10.96 & 0.12 & 19.85 \\
\hline 014 & -6.10 & 21.67 & 15.33 & 27.08 & 1.33 & 21.46 & 0.17 & 44.71 \\
\hline 015 & -4.10 & 22.67 & 14.56 & 25.32 & 0.74 & 12.42 & 0.13 & 50.49 \\
\hline 016 & -4.10 & 19.62 & 14.56 & 25.32 & 0.74 & 12.42 & 054 & 105.64 \\
\hline 017 & -3.40 & 12.46 & 15.89 & 33.11 & 2.00 & 21.30 & 0.17 & 68.18 \\
\hline 018 & -3.66 & 18.53 & 12.98 & 31.74 & 1.52 & 25.00 & 0.26 & 84.43 \\
\hline 019 & -4.39 & 12.40 & 14.70 & 31.69 & 1.84 & 40.61 & 0.08 & 8.08 \\
\hline 020 & -4.15 & 17.84 & 16.86 & 27.46 & 0.65 & 12.07 & 0.01 & 1.82 \\
\hline 021 & -3.72 & 21.24 & 15.45 & 24.39 & 1.22 & 7.68 & 0.20 & 168.14 \\
\hline 022 & -1.71 & 16.96 & 16.61 & 26.52 & 1.26 & 12.62 & 0.15 & 65.86 \\
\hline 023 & -3.76 & 12.84 & 14.98 & 32.04 & 1.51 & 13.21 & 017 & 128.72 \\
\hline 024 & 2.59 & 14.14 & 13.85 & 31.24 & 0.87 & 14.01 & 0.14 & 101.39 \\
\hline 025 & -1.70 & 16.42 & 14.79 & 28.85 & 1.25 & 33.87 & 0.11 & 79.43 \\
\hline 026 & 3.03 & 27.02 & 16.49 & 18.69 & 1.22 & 12.31 & 0.03 & 48.75 \\
\hline 027 & -1.42 & 24.64 & 15.85 & 21.33 & 0.72 & 14.96 & 0.27 & 75.60 \\
\hline 028 & -0.79 & 12.30 & 15.58 & 31.75 & 0.40 & 13.70 & 0.08 & 61.52 \\
\hline 029 & -1.18 & 18.45 & 16.33 & 26.62 & 1.09 & 15.66 & 0.12 & 35.22 \\
\hline 030 & -1.36 & 33.28 & 13.28 & 18.78 & 0.46 & 48.72 & 0.5 & 47.34 \\
\hline 031 & -3.66 & 18.53 & 12.98 & 31.74 & 1.52 & 25.00 & 0.42 & -1.34 \\
\hline 032 & -1.82 & 20.64 & 17.14 & 23.76 & 0.88 & 40.90 & 0.12 & 73.24 \\
\hline 033 & -0.62 & 16.61 & 15.00 & 28.21 & 2.32 & 11.87 & 0.12 & 18.83 \\
\hline 034 & -2.33 & 25.62 & 16.21 & 21.21 & 0.30 & 9.89 & 0.06 & 82.50 \\
\hline 035 & -6.35 & 25.34 & 15.17 & 25.91 & 0.89 & 35.38 & 0.33 & 210.62 \\
\hline 036 & -6.35 & 26.34 & 15.17 & 25.91 & 0.89 & 35.38 & 0.33 & 138.38 \\
\hline 037 & -9.22 & 27.66 & 15.00 & 20.23 & 1.02 & 25.71 & 1.76 & 148.42 \\
\hline 038 & 0.15 & 24.33 & 17.21 & 21.88 & 3.19 & 8.25 & 0.14 & 48.42 \\
\hline 039 & -0.58 & 22.69 & 14.51 & 23.35 & 0.75 & 7.08 & 0.18 & 76.08 \\
\hline 040 & -0.08 & 23.68 & 17.70 & 21.33 & 0.83 & 8.12 & 0.23 & 26.07 \\
\hline 041 & -5.02 & 22.27 & 15.68 & 22.79 & 1.21 & 7.06 & 0.20 & 132.75 \\
\hline 042 & 4.06 & 22.20 & 16.95 & 25.49 & 1.83 & 9.96 & 0.47 & 79.85 \\
\hline 043 & -5.71 & 20.11 & 16.99 & 19.19 & 1.56 & 7.49 & 0.44 & 204.23 \\
\hline 044 & -9.22 & 27.66 & 15.00 & 20.23 & 1.02 & 25.71 & 1.15 & 128.38 \\
\hline 045 & -6.35 & 18.81 & 15.24 & 25.12 & 2.02 & 13.00 & 0.18 & 36.53 \\
\hline 046 & 0.32 & 20.47 & 17.23 & 23.52 & 1.08 & 9.04 & 0.34 & 49.41 \\
\hline 047 & -11.21 & 19.17 & 17.49 & 26.23 & 1.81 & 11.54 & 0.28 & 160.56 \\
\hline 048 & -2.72 & 18.60 & 16.71 & 25.19 & 1.48 & 17.98 & 0.11 & 69.30 \\
\hline 049 & -1.99 & 21.95 & 15.12 & 25.44 & 1.16 & 13.30 & 0.18 & 23.96 \\
\hline 050 & -8.90 & 20.25 & 17.14 & 26.91 & 3.68 & 16.53 & 0.29 & 67.32 \\
\hline 051 & -6.38 & 18.03 & 18.03 & 24.06 & 2.27 & 21.13 & 0.20 & 149.62 \\
\hline
\end{tabular}




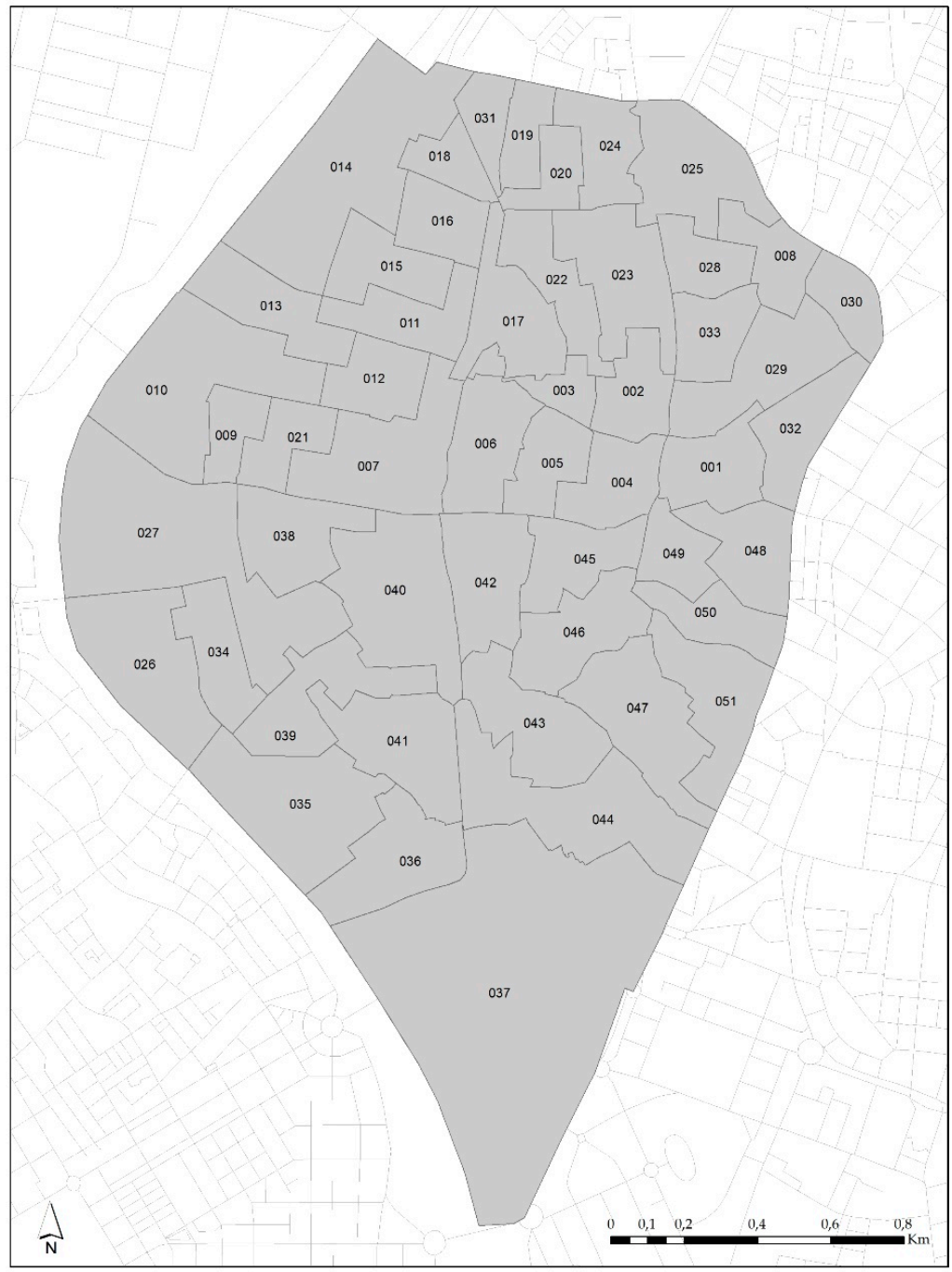

Figure 3. Sections tract distribution. Source: own production.

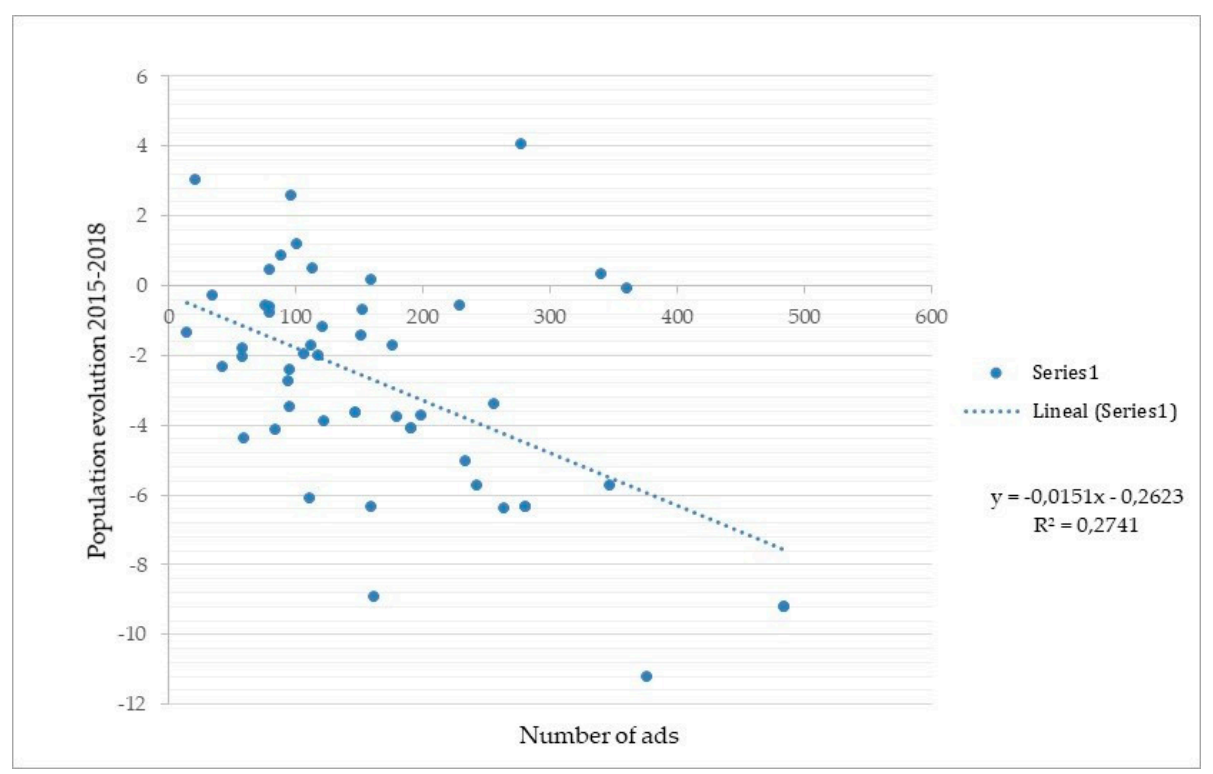

Figure 4. OLS population evolution 2015-2018/tourist rental housing. Source: own production. 


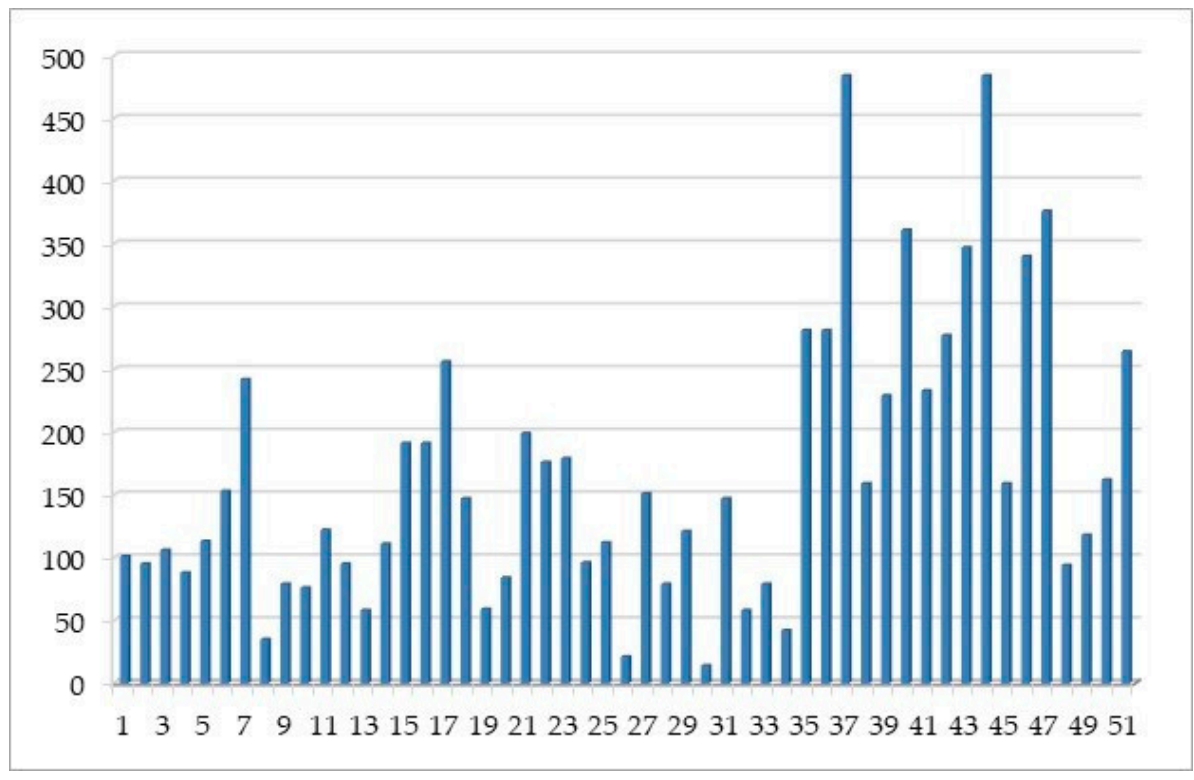

Figure 5. Distribution of tourist housing rental ads. Source: own production.
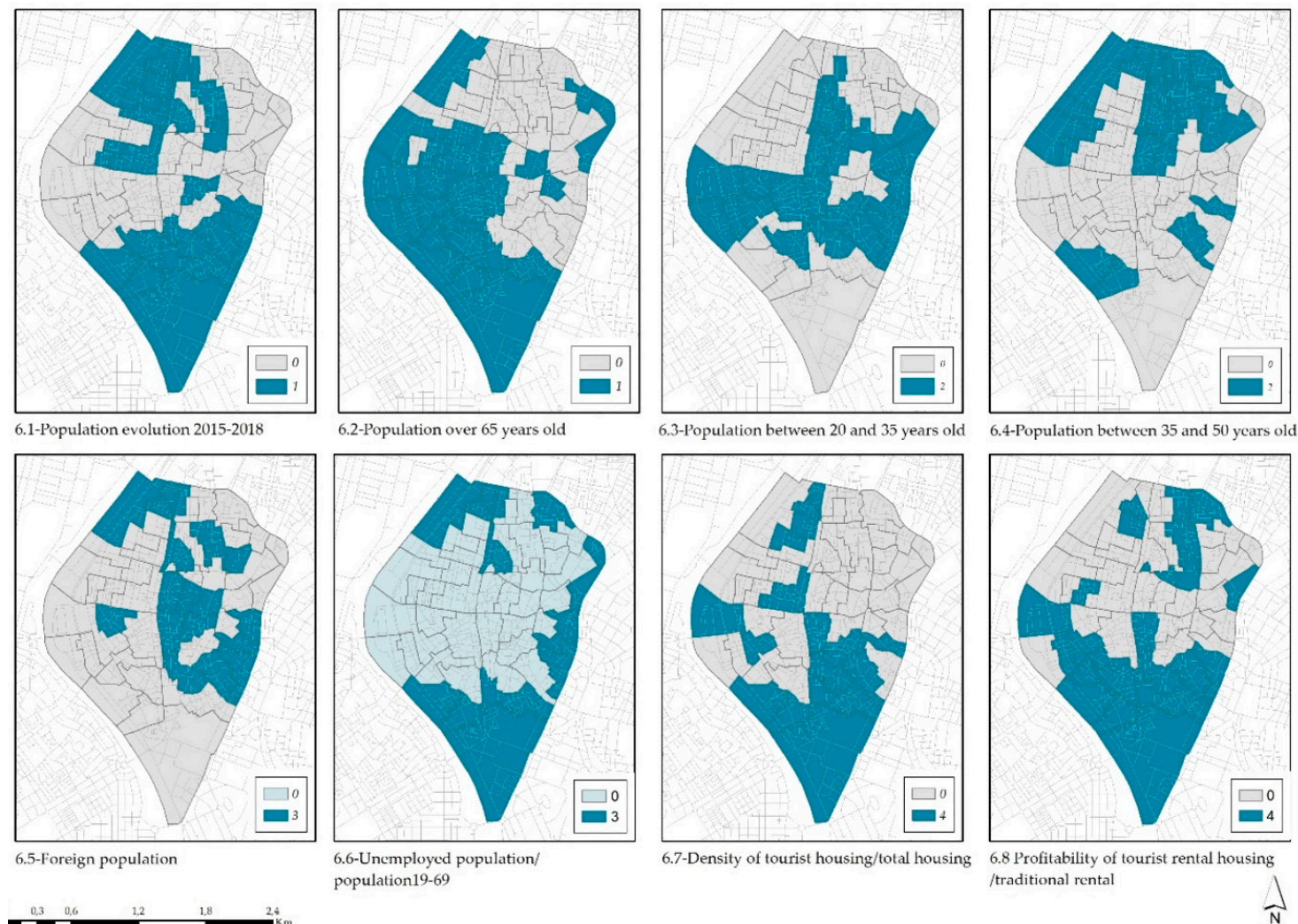

Figure 6. Map of result of the variables in the historic center of Seville. Source: own production.

Without going into detail for each indicator, some notable results are:

- There is a predominance of spaces that are losing population or have an elderly population, especially in southern and western parts of the historic center. On the other hand, this progressive population decline and ageing is a common pattern in Spanish historic centers;

- The contrary situation appears in a central zone comprising tracts with a higher presence of young people between 20 and 35 years old, with most needing to live in rented housing; 
- The concentration of economic immigrants, usually with low income levels, presents a distribution hard to interpret due to its duality. This is because there is a notable presence in tracts at the eastern and the northern ends of the historic center (where rents are predictably cheaper), though they also appear in its southern part in areas with a higher economic level. This may possibly be due to a combination of factors that are hard to interpret with the available sources (domestic help, presence in some deteriorating buildings in the center with low rents, population contingents from those countries but with higher income levels, etc);

- The proportion of unemployed, as an essential socioeconomic variable, does present spatial distribution in accordance with the previously indicated patterns, as it is concentrated in the northern and the eastern sections of the historic center, traditionally considered to have lower economic and social standing;

- Regarding the variables most directly linked to TRH, the map of the ratio of TRH/total number of residences shows the highest density around the main traditional tourist resources [monuments designated as World Heritage by the United Nations Educational, Scientific and Cultural Organization (UNESCO), in the southern part of the historic center, and areas along the Guadalquívir River] as well as in new tourist spaces of the city, such as close to the Alameda de Hércules in the northern part of the historic center. As for the variable concerning the profitability of tourist rentals versus residential rentals, it largely reproduces the previous map, indicating high profitability in both traditional and recent tourism spaces. However, it also shows above average values in sections of the northeast end of the historic center.

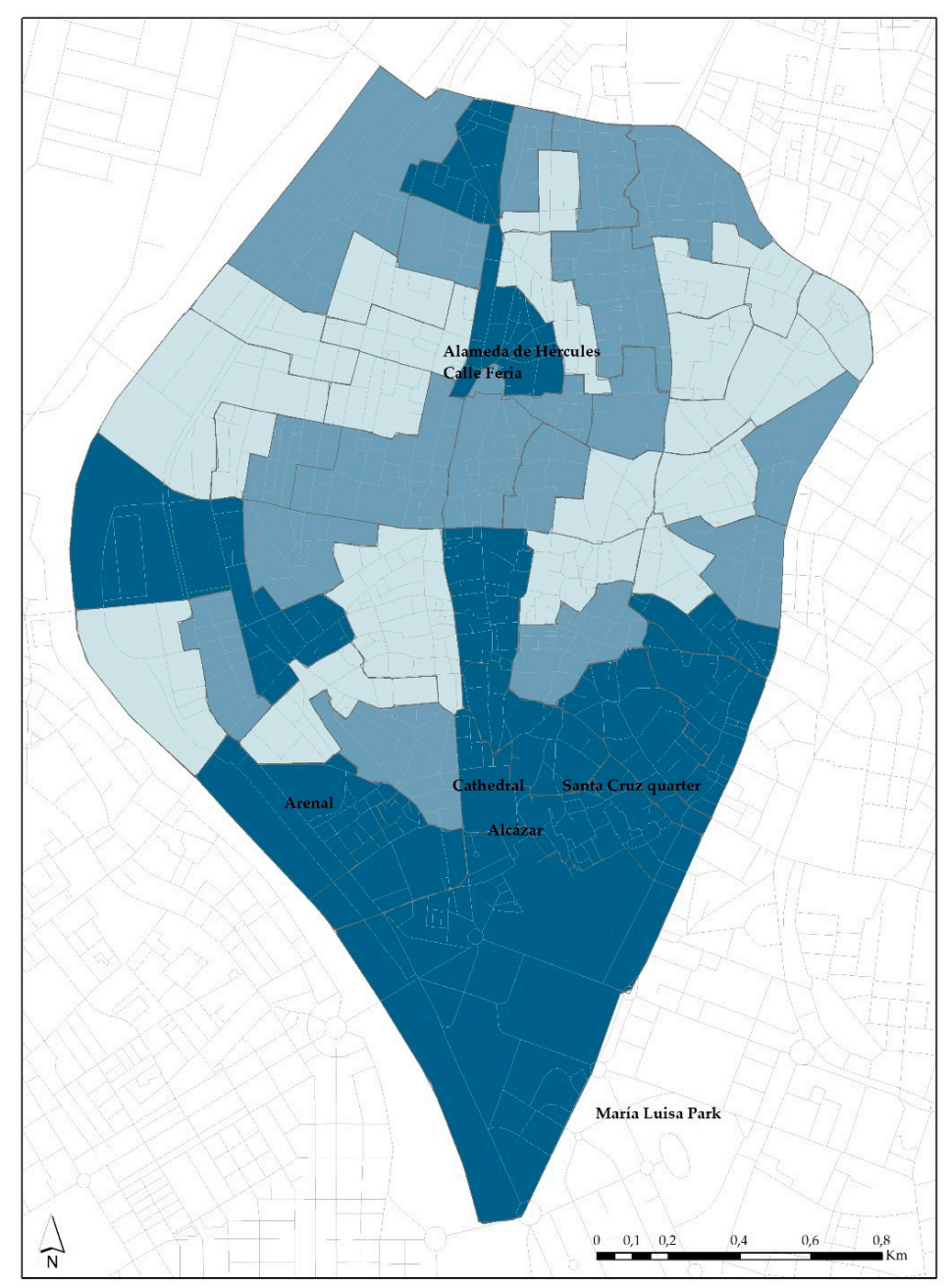

Figure 7. Vulnerability indicator in the historic center of Seville. Source: own production. 
Lastly, the final map of the vulnerability indicator (see Figure 7) shows how the areas with higher vulnerability associated with the presence of TRH are those most heavily visited by tourists in the southern part of the historic center, close to major traditional tourist resources (Cathedral, Alcázar, Santa Cruz quarter, María Luisa Park, banks of the Guadalquivir River). This notwithstanding, and very importantly for the aims of this article, a notable area also appears in the north in the new tourism area around Alameda de Hércules/Calle Feria.

For its part, the less vulnerable areas are situated in the central zone of the historic center, which is less attractive for tourists and has not lost population in recent years.

\section{Discussion}

Despite the importance acquired by the topics of vulnerability and touristification processes in Spanish cities, research has generally suffered from insufficient data at an intra-urban scale, a problem this article aimed to confront. For example, the last census of population and housing dates back to 2011, whereby the figures it offers have become obsolete for studying such a recent phenomenon. The shortage of information is combined with its differentiated processing by administrations. While, in some cases, the reference unit is the census tract, in others, larger and less standardized units such as neighborhoods are used. For this article, it was possible to obtain more detailed spatial information due to the availability of the Longitudinal Population Database of Andalusia produced by the Andalusian Institute of Statistics and Mapping, which supplies some population information in a grid with squares measuring $250 \mathrm{~m}$ on each side; this information is very detailed, though it had to be transferred to the tracts. All these circumstances limit ascertainment of the true socioeconomic reality of the intra-urban spatial units and the extent of touristification's impact on residents.

There are some research limitations that can affect the study of this topic. Regarding the sources used, there was a notable lack of availability of the sought-after scale (census tracts) for two variables essential for analyzing the article's subject, i.e., the evolution of residential rents and the income levels of the population. This information would have been very useful to differentiate areas of the historic center regarding the main factors (and the intensity of said factors) causing populations to leave (residential rent increases in recent years) as well as one of the main differential elements indicating the population's vulnerability-their income level. Given that, in Spain, there are no statistics that break down that information at the intended scale, other variables that were available (or could be calculated by the authors) were used to understand their significance, such as estimating the difference in benefits for owners between residential rentals of their buildings or tourist rentals, or determining socioeconomic variables close to income level such as distribution of unemployment rates. It was therefore possible to mitigate the insurmountable lack of relevant statistical data without renouncing the research objectives.

Likewise, the use of Datahippo as a source to analyze the presence of TRH was also a limitation. This source is very useful since it groups together the existing offers on Airbnb, HomeAway, HouseTrip, and OnlyApartments platforms and is usually used in this type of study. However, it presents a problem regarding the location of these homes in the urban fabric. The problem is that these platforms do not offer the exact location of the house (until a specific one is actually hired). In this way, the location of each house in Datahippo is located within a radius of $150 \mathrm{~m}$ from its real location. This is not a problem for larger space units, but when working with census sections, it introduces a certain margin of error since it is only an approximation of $150 \mathrm{~m}$. A dwelling might appear in one census section while, in reality, it is located in another, modifying the calculation of the indicator obtained. However, we deemed that, statistically, these errors were balanced out between neighboring census sections, thus there should have been no significant alteration of the results in the end.

In the same way, within the study limitations, it is worth noting the lack of data on residential mobility in the interior of the city. This information would be the key to exactly determining the population volumes that are changing their residence between the census sections. This in combination with the presence of TRH would have allow correlations between the two phenomena that demonstrate 
the process of expulsion of residents, their exact numbers, and the places of origin and destination of the mobility processes. However, these data are not available in local administrations, thus they were not provided despite having been requested.

From the standpoint of the results obtained, the calculated and the mapped data concerning the eight base variables are very diverse. Altogether and broadly speaking, the permanence (with some recent changes that are discussed herein) of the historic patterns of division in the city of Seville stands out. Differences are seen between some working-class neighborhoods with lower incomes situated in the north and the east versus others in the south and the west, where the city's emblematic landmarks are traditionally concentrated along with its centers of administrative, religious, judicial, and academic power and its wealthier population. It is significant that this duality, which has its origins in the formation of the great Islamic city of the 12th century, can still be clearly perceived today and is a factor that helps explain social vulnerability differences within the historic center. For example, it can be clearly seen in the result from the variable for proportion of unemployed over the whole working age population Figure 6 (map 6.6), which is the most significant of the social differences between the different zones and very closely reproduced the traditional spatial pattern mentioned above.

Regarding the other variables used, the meaning of the results is disputable. For example, the level of population ageing might a priori be considered a relevant factor for vulnerability when faced with touristification, given that people over 65 may be more sensitive to the respective problems or changes in their everyday lives, as is occurring in both public spaces and in the buildings themselves. However, the analysis showed a scant statistical correlation (practically nil, with an $\mathrm{R}^{2}$ of 0.037 ) that would ratify the initial approach. The explanation for this is that the main vulnerability factor concerns the system governing housing occupation according to whether it is rented or owned, regardless of the age of the dwellers. Hence, in the Spanish situation, the elderly mostly live in housing that they own, regardless of their economic level, as they have had many long years to acquire their homes by means of mortgage credit. For that reason, they are anchored to their owned residence and will not move to other parts of the city, even when upset about perceived transformations in their day-to-day environment. Indeed, they could not do so even if they wanted to due to the high current prices for buying another home. Also, the distribution of the ageing variable in the historic center, though it seems to dominate in neighborhoods with higher income, does not supply very decisive conclusions. This situation, as indicated in the section on methodology, justifies the low weighting factor assigned to this variable, although it should not be ignored.

Based on the previously referenced approach (that the need to dwell in residential rentals is a decisive factor for assessing vulnerability before the expansion of tourist rentals), variables close to that reality were sought, given the inexistence of information about the volume of people who live in rented homes. An attempt was made to resolve that lack by ascertaining the proportion of the population between 20 and 35 years old (principally students from elsewhere or workers in the first career levels) who are still unable to acquire a home and therefore need to live in rented housing and the proportion of the population between 35 and 50 years old (young households with young children) who, according to the literature indicated in the methodology section, are the group most affected by evictions. Both age groups contributed nuances of interest, given the intention for the indicator to cover the highest possible number of problems and groups liable to being affected by vulnerability, depending on the available information sources.

Among the variables used, also noteworthy is the result obtained for the profitability difference between tourist rentals and residential rentals. This is considered one of the most significant results of the article. This is because that difference is the fundamental factor for changing the use of buildings, which has shifted from long-term residential rental to short-term tourist rentals with high user rotation. The higher the profitability difference between one and the other situation is, the higher the number of owners who decide to modify the use of their property will be, reducing the ability of the population seeking rental housing to reside in those neighborhoods. The result obtained, shown in Figure 6 (map 6.8), offers two readings of great interest. On the one hand, it is confirmation of the notable difference 
of profitability in the southern and the western sections, which was foreseen because they are wealthier areas with higher property prices in addition to being more touristy due to the closeness to the city's main monuments and landmarks. On the other hand, various sections of the northern historic center clearly stand out, specifically some of its most depressed areas, which are undergoing a rapid process of gentrification and touristification (as indicated in the bibliographic review of the case of Seville). This second result is extremely important, as it statistically shows processes heretofore only indicated qualitatively or hypothetically. From the standpoint of prospective analysis, we could anticipate, in coming years, a situation of serious difficulty for rental residents in that zone, which is also one of those most affected by unemployment. For all these reasons, the certain possibility that these sections at the north end of the historic center will see processes of eviction and population replacement, as other areas have already experienced, can be asserted.

Lastly, regarding the final result of the vulnerability indicator (Figure 7), which is the article's fundamental contribution, it reveals high vulnerability, as previously indicated, in two parts of the historic center. First, to a greater extent, are the southern and the western sections close to the city's emblematic and heavily visited spaces. This should be interpreted in the sense that the population residing there, who currently present features of sensitiveness to the phenomenon (basically because they live in rented homes and have low income and, for example, are affected by unemployment), will face an extreme degree of vulnerability, running the certain risk of being forced to move to other areas of the city in the near future. Indeed, in the areas that can be properly defined as tourist spaces (for example, the Santa Cruz quarter), the monoculture of this activity makes it hard to believe that the population such as the one referred to can live there nowadays.

Second, and as an even more notable result due to its novelty, a second set of tracts stands out with less surface area in the northern part of the historic center (the area around Alameda de Hércules and Calle Feria). This finding is worth emphasizing because it is a traditionally depressed environment that has serious problems of urban deterioration and social exclusion but which is in the process of transforming to become a new tourist space in the city after a series of public and private renewal actions in the last two decades (as indicated in the section presenting the case of Seville). Since the beginning of the 21st century, it has become an area where the creative classes and new cultural and specialized restaurant spaces are concentrated, thus experiencing gradual gentrification. The result shown in the map indicates that, after being included in the city's tourist circuits, it now has a large amount of TRH, whereby it is one of the spaces with higher vulnerability to the phenomenon in the entire historic center. This caused a historic break from what had been the patterns for the locations of activities in the city throughout the 20th century, and the result of the vulnerability indicator seems to portend that the phenomenon is not finished and that a gradual replacement of those creative classes (with an alternative or Bohemian orientation) and the few remaining original inhabitants by contingents of tourists lodged in rental housing can be predicted for the future.

It can also be indicated that the vulnerability indicator has its lowest values in a central zone of tracts that cross the historic center from east to west. These are traditionally transition environments peopled by a large variety of middle classes who currently seem to be the ones that largely maintain their traditional urban functions in contrast with the tourist spaces to the south and the gentrified ones to the north.

\section{Conclusion}

As a first conclusion, it can be stated that the three objectives planned for this article were fulfilled. First of all, the concept of social vulnerability was studied in depth at the level of theory and review of the literature, as was its current relationship with the phenomenon of touristification and the impact of manifestations of the so-called sharing economy, such as the proliferation of rental housing for tourists in cities' historic centers.

Second, as a main contribution of this article, a vulnerability indicator associated with the TRH was designed based on the selection and the statistical processing of eight variables of demographic, 
socioeconomic, and housing natures. The result was the delimitation of zones of high, medium, and low vulnerability in the cities.

Third, the applicability of this indicator in a real case, the city of Seville, was tested due to the volume of tourism activity attained therein. This application led to concrete results by mapping vulnerability before the phenomenon at the scale of census tracts in its historic center.

The work undertaken shows that Seville has joined one of the world's major urban trends- the gradual increase of tourism function in central areas of the city, which is displacing other uses or previous activities as well as part of the previous residential population. It was noted how the phenomenon's patterns in Seville very much resemble those in other cities heavily frequented by tourists.

The method followed implies an advance in quantitative and statistical treatment of a phenomenon that, until now, had basically been approached with qualitative or descriptive focuses or at a scale of spatial breakdown with less detail. The design of the methodology for establishing the indicator is the article's greatest contribution.

Finally, it must be noted that this kind of research can generate tools to support decision making by public administrations responsible for alleviating the phenomenon's negative effects so that the residents' rights to the city can prevail over the interests of tourism and property agents.

Author Contributions: A.F.-T, M.J.P. and C.M. contributed to the conception and design, data collection, data analysis and manuscript preparation. C.M. and M.J.P. to statistical analysis. M.J.P. to proofreading and editing. C.M. to Mapping. A.F.-T. to the result interpretation.

Funding: This research was funded by the Spanish Ministry of Economy and Competitiveness (MINECO) Transformations of the historic urban landscape induced by tourism: contradictions and controversies, government and local governance (CSO2016-75470-R), New Models for Governing Cities and Intervention in Urban Spaces in the Post-Crisis Period (CSO 2016-75236-C2-1-R) and Territorial intelligence versus tourism growth. Planning and managing destinations for the new cycle of real estate expansion (PGC2018-095992-B-I00).

Conflicts of Interest: The authors declare no conflict of interest.

\section{References}

1. González Kichner, B. La ciudad tradicional como objeto de consumo: Banalización del espacio público a imagen de los centros comerciales suburbanos; Universidad Politécnica de Madrid: Madrid, Spain, 2011.

2. Lois, R.C.; Piñeira, M.J. The revival of urban social and neighbourhood movements in Spain:a geographical characterization. Di Erde 2015, 146, 127-138.

3. Llano Ortiz, J.C. El estado de la pobreza seguimiento del indicador de pobreza y exclusión social en España 2008-2017; EAPN España: Madrid, Spain, 2018.

4. United Nations. Report on the World Social Situation 2003: Social Vulnerability-Sources and Challenges; United Nations: Rome, Italy, 2003.

5. Durán Villa, F.R.; Piñeira Mantiñán, M.J. Evictions and the social crisis in Spanish cities. In Urban Challenges in a Complex World: Resilience, Governance and Changing Urban; Moore-Cherry, N., Ed.; University College Dublin \& IGU: Dublin, Ireland, 2015; pp. 80-85.

6. Wehrhahn, R. Contentious urban housing politics in European metropolises between financialisation, dispossession and re-possession: Jahrbuch StadtRegion. In Housing and Housing Politics in European Metropolises; Wehrhahn, R., Pohlan, J., Hannemann, C., Othengrafen, F., Schmidt-Lauber, B., Eds.; Springer: Wiesbaden, Germany, 2019; pp. 3-20.

7. Koutrolikou, P. Changing landscapes of urban citizenship: Southern Europe in times of crisis. Citizsh. Stud. 2017, 21, 1-14.

8. Heffernan, E.; McHale, J.; Moore-Cherry, N. Debating Austerity in Ireland: Crisis, Experience and Recovery; Royal Irish Academy: Dublin, Ireland, 2017.

9. Janoschka, M. Who Loses and Who Wins in a Housing Crisis? Lessons from Spain and Greece for a Nuanced Understanding of Dispossession. Hous. Policy Debate 2017, 28, 1-18.

10. Amendola, N.; Rossi, M.C.; Vecchi, G. Vulnerability to Poverty in Italy; Working Papers; Department of Economics and Statistics: Torino, Italy, 2012; Volume 007, pp. 1-16. 
11. Sánchez, S.; Méndez, R.; Prada, J. The "shrinking cities" phenomenon in Spain: An approach to causes, effects and revitalization strategies using a case study of Avilés. In New Trends in the XXI Century: Spanish Geography; Spanish Committee IGU: Madrid, Spain, 2012; pp. 252-266.

12. Piñeira, M.J.; Trillo, J.M. The effect of the crisis on vulnerable neighbourhoods: An approximation of the Spanish context through a case study (A Coruna, Galicia). In Crisis, Globalization and Social and Regional Imbalances in Spain; Spanish Commitee IGU: Madrid, Spain, 2016; pp. 136-148.

13. Piñeira, M.J.; Lois, R.C.; González, J.M. New models of urban governance in Spain during the post-crisis period: The fight against vulnerability on a local scale. Territ. Politics Gov. 2019, 7, 336-364. [CrossRef]

14. Alaminos, A.; Penalva, F.; Domenech, Y. Reacciones comunitarias a la crisis económica y social en España. Azarbe. Revista Internacional de Trabajo Social y Bienestar 2014, 3, 47-53.

15. Díaz Hernández, R.; Domínguez Mujica, J.; Parreño Castellano, J.M. Vulnerabilidad urbana y segregación residencial de la población extranjera no comunitaria en las ciudades más populosas de Canarias. In Proceedings of the XXII Coloquio de Historia Canario-Americana, Canarian Islands, Spain, 3-7 October 2016.

16. Castellano, J.M.; Mujica, J.D.; Martín, M.T.; Hernández, J.B.; García, T.P. Real estate dispossession and evictions in Spain: A theoretical geographical approach. Boletín de la Asociación de Geógrafos Españoles 2019, 80, 1-25. [CrossRef]

17. Carman, M.; Vieira, N.; Segura, R. Segregación y Diferencia en la Ciudad; FLACSO, CLACSO, Ministerio de Desarrollo Urbano y Vivienda: Quito, Ecuador, 2013.

18. Nel-Lo, O. Evolution of the Urban Segregation to Catalonia 2001-2012. Presentation and Preliminary Results; Autonomous University of Barcelona: Bellaterra, Spain, 2014.

19. Nel-Lo, O. Transform the City with Citizenship. Criteria and Reflections for the Barrios Plan of Barcelona; Ayuntamiento de Barcelona: Barcelona, Spain, 2017.

20. Ministry of Public Works. Atlas of Urban Vulnerability in Spain; Ministry of Public Works: Madrid, Spain, 2011.

21. Ministry of Public Works. Urban Analysis of Vulnerable Neighborhoods in Spain; Ministry of Public Works: Madrid, Spain. Available online: www.fomento.gob.es (accessed on 4 June 2019).

22. Méndez, R.; Abad, L.D.; Echaves, C. Atlas de la crisis; Tirant lo Blanch: Valencia, Spain, 2015.

23. Alguacil, J.A.; Camacho, J.; Hernández, A. La vulnerabilidad urbana en España. Identificación y evolución de los barrios vulnerables. Empiria. Revista de Metodología de Ciencias Sociales 2014, 27, 73-94. [CrossRef]

24. Arias, F. La desigualdad urbana en España; Ministerio de Fomento: Madrid, Spain, 2000.

25. Subirats, J.; Martí-Costa, M. Ciudades, vulnerabilidades y crisis en España; Junta de Andalucía: Sevilla, Spain, 2014.

26. Ministry for Ecological Transition. Air Quality Assessment Report in Spain; MITECO: Madrid, Spain, 2019.

27. Hernández-Ramírez, J. La voracidad del turismo y el derecho a la ciudad. Revista Andaluza de Antropología 2018, 15, 22-46. [CrossRef]

28. Díaz Parra, I. La gentrificación en la cambiante estructura socioespacial de la ciudad. Biblio $3 W$ Revista Bibliográfica de Geografía y Ciencias Sociales 2013, XVIII, 1030.

29. Forno, F.; Garibaldi, R. Sharing economy in travel and tourism: The case of home-swapping in Italy. J. Qual. Assur. Hosp. Tour. 2015, 16, 202-220. [CrossRef]

30. Sigala, M. Collaborative commerce in tourism: Implications for research and industry. Curr. Issues Tour. 2015, 20,1-20. [CrossRef]

31. Tussyadiah, I.P.; Pesonen, J.O. Impacts of peer-to-peer accommodation use on travel patterns. J. Travel Res. 2015, 55, 1022-1040. [CrossRef]

32. Dredge, D.; Gyimothy, S. Collaborative Economy and Tourism: Perspectives, Politics, Policies and Prospects; Springer: Cham, Switzerland, 2017.

33. Ioannides, D.; Röslmaier, M.; Van der Zee, E. Airbnb as an instigator of 'tourism bubble' expansion in Utrecht's Lombok neighbourhood. Tour. Geogr. 2018. [CrossRef]

34. Christensen, C.; Raynor, M. The Innovator's Solution: Creating and Sustaining Successful Growth; Harvard Business Review Press: Harvard, MA, USA, 2003.

35. Guttentag, D. Airbnb: Disruptive innovation and the rise of an informal tourism accommodation sector. Curr. Issues Tour. 2015, 18, 1192-1217. [CrossRef]

36. Dredge, D.; Gyimothy, S. The collaborative economy and tourism: Critical perspectives, questionable claims and silenced voices. Tour. Recreat. Res. 2015, 40, 286-302. 
37. Ikkala, T.; Lampinen, A. Defining the price of hospitality: Networked hospitality exchange via Airbnb. In Proceedings of the 17th ACM Conference on Computer Supported Cooperative Work \& Social Computing, Baltimore, MD, USA, 15-19 February 2014; ACM: Baltimore, MD, USA, 2014; pp. 173-176.

38. Ikkala, T.; Lampinen, A. Monetizing Network Hospitality: Hospitality and Sociability in the Context of Airbnb. In Proceedings of the 18th ACM Conference on Computer Supported Cooperative Work \& Social Computing, Vancouver, BC, Canada, 14-18 March 2015; ACM: Vancouver, BC, Canada, 2015; pp. 1033-1044.

39. Díaz Armas, R.J.; Gutiérrez Taño, D.; García Rodríguez, F.J. Airbnb como nuevo modelo de negocio disruptivo en la empresa turística: Un análisis de su potencial competitivo a partir de las opiniones de los usuarios. In Proceedings of the XVIII Congreso AECIT (Asociación Española de Expertos Científicos en Turismo), Turismo: Liderazgo, Innovación y Emprendimiento, 26-28 November 2014; AECIT: Benidorm, Spain. Available online: https://aecit.org/files/congress/18/papers/29.pdf (accessed on 4 June 2019).

40. McNamara, B. Airbnb: A not-so-safe resting place. Colo. Technol. Law J. 2015, 13, 149-169.

41. Zervas, G.; Proserpio, D.; Byers, J. A First Look at Online Reputation on Airbnb, Where Every Stay is Above Average. SSRN 2015. Available online: https://ssrn.com/abstract=2554500 (accessed on 4 June 2019). [CrossRef]

42. Stors, N.; Kagermeier, A. Share Economy in Metropolitan Tourism. The role of authenticity-seeking. In Metropolitan Tourism Experience Development; Tózsa, I., Zátori, A., Eds.; Regional Studies Association: Budapest, Hungary, 2015; pp. 90-104.

43. Arias Sans, A.; Quaglieri Dominguez, A. Unravelling Airbnb: Urban perspectives from Barcelona. In Reinventing the Local in Tourism: Producing, Consuming and Negotiating Place; Russo, A.P., Richards, G., Eds.; Channel View Publications: Bristol, UK, 2016; pp. 209-228.

44. Gutierrez, J.; Garcia-Palomares, J.C.; Romanillos, G.; Salas-Olmedo, M.H. Airbnb in tourist cities: Comparing spatial patterns of hotels and peer-to-peer accommodation. Tour. Manag. 2017, 62, 278-291. [CrossRef]

45. Dudas, G.; Vida, G.; Kovalcsik, T.; Boros, L. A socio-economic analysis of Airbnb in New York City. Reg. Stud. 2017, 7, 135-151. [CrossRef]

46. Yrigoy, I. The impact of Airbnb in the urban arena: Towards a tourism-led gentrification? The case study of Palma old quarter. In Turismo y Crisis. Turismo Colaborativo y Ecoturismo; Blazquez, M., Mir-Gual, M., Murray, M., Pons, G.X., Eds.; Societat d'Història Natural de les Balears: Balearic Islands, Spain, 2016; pp. 281-289.

47. Colomb, C.; Novy, J. (Eds.) Protest and Resistance in the Tourist City; Routledge: London, UK, 2017.

48. Gotham, K.F. Tourism gentrification: The case of New Orleans' vieux carre (French Quarter). Urban Stud. 2005, 42, 1099-1121. [CrossRef]

49. Lee, D. How Airbnb short-term rentals exacerbate Los Angeles's affordable housing crisis: Analysis and policy recommendations. Harv. Law Policy Rev. 2016, 10, 229-253.

50. Oppilard, F. From San Francisco's 'Tech Boom 2.0' to Valparaiso's UNESCO World Heritage Site: Resistance to tourism gentrification from a comparative political perspective. In Protest and Resistance in the Tourist City; Colomb, C., Novy, J., Eds.; Routledge: London, UK, 2017; pp. 129-151.

51. Füller, H.; Michel, B. 'Stop being a tourist!' New dynamics of urban tourism in Berlin-Kreuzberg. Int. J. Urban Reg. Res. 2014, 38, 1304-1318. [CrossRef]

52. Gant, A. Tourism and Commercial Gentrification. Available online: www.rc21.org/en/wpcontent/uploads/ 2014/12/E4-C\%C3\%B3cola-Gant.pdf (accessed on 4 June 2019).

53. Blázquez-Salom, M.; Blanco-Romero, A.; Guall, J.; Murray, I. Tourist gentrification of retail shops in Palma (Majorca). In Overtourism: Excesses, Discontents and Measures in Travel and Tourism; CABI Publishing: London, UK, 2019; pp. 39-69.

54. Sundararajan, A. The 'Gig Economy' Is Coming. What Will it Mean for Work? Available online: www. theguardian.com/commentisfree/2015/jul/26/will-we-get-by-gig-economy (accessed on 4 June 2019).

55. Maitland, R. Tourists, the creative class and distinctive areas in major cities: The roles of visitors and residents in developing new tourism areas. In Tourism, Creativity and Development; Richards, G., Wilson, J., Eds.; Routledge: New York, NY, USA, 2007; pp. 73-86.

56. Zervas, G.; Byers, J. The Rise of the Sharing Economy: Estimating the Impact of Airbnb on the Hotel Industry. 2016. Available online: http://cs-people.bu.edu/dproserp/papers/airbnb.pdf (accessed on 6 June 2019).

57. Fuentes, R.; Navarrete, L. Tourists in hotels versus holiday homes: Economic impact and characterization. Tour. Rev. Int. 2016, 20, 177-195. [CrossRef] 
58. Johnson, C. Gentrifying New Orleans: Thoughts on race and the movement of capital. Souls 2015, 17, 175-200. [CrossRef]

59. Ioannides, D.; Petridou, E. Contingent neoliberalism and urban tourism in the United States. In Neoliberalism and the Political Economy of Tourism; Mosedale, J., Ed.; Routledge: Ney York, NY, USA, 2016; pp. 21-35.

60. Gil, J.; Sequera, J. Expansión de la ciudad turística y nuevas resistencias. El caso de Airbnb en Madrid. Empiria Revista de Metodología de Ciencias Sociales 2018, 41, 15-32. [CrossRef]

61. Nofre, J.; Giordano, E.; Eldridge, A.; Martins, J.C.; Sequera, J. Tourism, nightlife and planning: Challenges and opportunities for community liveability in La Barceloneta. Tour. Geogr. 2018, 20, 377-396. [CrossRef]

62. Merante, M.; Horn, K.M. Is Home Sharing Driving up Rents? Evidence from Airbnb in Boston. J. Hous. Econ. 2017, 38, 14-24.

63. Pixová, M.; Sládek, J. Touristification and awakening civil society in postsocialist Prague. Protest and resistance in the tourist city. In Contemporary Geographies of Leisure, Tourism and Mobility; Routledge: London, UK, 2016; pp. 73-89.

64. Owyang, J. The Collaborative Economy. Altimeter Research Theme. Technol. Bus. Econ. Financ. 2013. Available online: www.slideshare.net/Altimeter/the-collaborative-economy (accessed on 4 June 2019).

65. Oskam, J.; Boswijk, A. Airbnb: The future of networked hospitality businesses. J. Tour. Futures 2016, 2, $22-42$. [CrossRef]

66. González, S.; Waley, P. Traditional retail markets: The new gentrification frontier? Antipode 2013, 45, $965-983$. [CrossRef]

67. Janoschka, M.; Sequera, J. Gentrification in Latin America: Addressing the politics and geographies of displacement. Urban Geogr. 2016, 37, 1175-1194. [CrossRef]

68. Requejo, J. Frente a la marabunta: Territorio y trabajo, bases del turismo responsable y sostenible". Razones de Utopía 2017, 2, 30-47.

69. Blanco-Romero, A.; Blázquez-Salom, M.; Canoves, G. Barcelona, Housing Rent Bubble in a Tourist City. Social Responses and Local Policies. Sustainability 2018, 10, 2043. [CrossRef]

70. Hoffman, L.M.; Fainstein, S.S.; Judd, D.R. (Eds.) Cities and Visitors: Regulating People, Markets, and City Space; Blackwell Publishing: Oxford, UK, 2003.

71. Temes, R. Valoración de la vulnerabilidad integral en las áreas residenciales de Madrid. EURE 2014, 40, 119-149. [CrossRef]

72. Galster, G.C.; Killen, S.P. The geography of metropolitan opportunity: A reconnaissance and conceptual framework. Hous. Policy Debate 1995, 6, 7-43. [CrossRef]

73. Villar, A.; Fernández-Tabales, A. Reconstruir la historia del turismo a través de la prensa: La evolución del espacio turístico de Sevilla (1915-2015). Cuadernos Geográficos de la Universidad de Granada 2018, 56, 290-321.

74. Mercado-Alonso, I.; Fernández-Tabales, A. Percepciones y valoraciones sociales del paisaje en destinos turísticos. Análisis de la ciudad de Sevilla a través de técnicas de investigación cualitativas. Cuadernos de Turismo 2018, 42, 355-383. [CrossRef]

75. Díaz-Parra, I. Procesos de gentrificación en Sevilla en la coyuntura reciente. Análisis comparado de tres sectores históricos: San Luis-Alameda, Triana y San Bernardo (2000-2006). Scr. Nova 2009, 13, 281-309.

76. García-García, A.; Fernández-Salinas, V.; Caravaca, I.; González-Romero, G. Actividades creativas, transformaciones urbanas y paisajes emergentes. El caso del casco norte de Sevilla. Documents d'Anàlisi Geogràfica 2016, 62, 27-54. [CrossRef]

77. Díaz-Parra, I. Viaje solo de ida. Gentrificación e intervención urbanística en Sevilla. EURE 2015, 41, 145-166. [CrossRef]

78. Díaz Parra, I.; Jover, J. Enclaves urbanos de éxito. Transformación urbanística, gentrificación y turismo en la Alameda de Hércules de Sevilla. In Capital Inmobiliario y Transformaciones del Espacio Urbano Contemporáneo; Universidad Nacional Autónoma de México: Mexico City, Mexico, 2018.

79. Jover, J.; Berraquero-Díaz, L.; Barrero-Rescalvo, M.; Jiménez-Talavera, A. Turistización y movimientos urbanos de resistencia: Experiencias desde Sevilla. In Ciudad de vacaciones. Conflictos urbanos en espacios turísticos; Milano, C., Mansilla, J.A., Eds.; Pol-len edicions: Barcelona, Spain, 2018; pp. 403-438.

80. Fundación Foessa. VIII Informe sobre exclusión y desarrollo social en España 2019. Available online: www.foessa.es/viii-informe (accessed on 4 June 2019).

81. Cruz Roja. Informe de la vulnerabilidad 2014. Estudios e innovación. Available online: www.cruzroja.es/ principal/web/estudios-e-innovacion/informes-de-vulnerabilidad (accessed on 4 June 2019). 
82. Observatorio DESC. Emergencia habitacional en Cataluña. Impacto de la crisis hipotecaria en el derecho a la salud y los derechos de la infancia. Available online: https://observatoridesc.org/es/node/4309 (accessed on 4 June 2019).

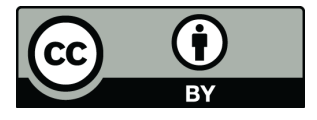

(C) 2019 by the authors. Licensee MDPI, Basel, Switzerland. This article is an open access article distributed under the terms and conditions of the Creative Commons Attribution (CC BY) license (http://creativecommons.org/licenses/by/4.0/). 